\title{
The tale of two genes: from next- generation sequencing to phenotype
}

\author{
Mersedeh Rohanizadegan, ${ }^{1}$ Aishwarya Siddharath, ${ }^{1}$ Kyle Retterer, ${ }^{2}$ \\ Christina Hung, ${ }^{1}$ and Olaf Bodamer ${ }^{1,3}$ \\ ${ }^{1}$ Division of Genetics and Genomics, Boston Children's Hospital, Harvard Medical School, Boston, \\ Massachusetts 02115, USA; ${ }^{2}$ GeneDx, Gaithersburg, Maryland 20877, USA; ${ }^{3}$ Broad Institute of MIT \\ and Harvard, Cambridge, Massachusetts 02142, USA
}

Abstract An 18-yr-old man with a history of intellectual disability, craniofacial dysmorphism, seizure disorder, and obesity was identified to carry a de novo, pathogenic variant in ASXL1 (c.4198G > T; p.E1400X) associated with the diagnosis of Bohring-Opitz syndrome based on exome sequencing. In addition, he was identified to carry a maternally inherited and likely pathogenic variant in MC4R (c.817C>T; p.Q273X) associated with monogenic obesity. Dual genetic diagnosis occurs in $4 \%-6 \%$ of patients and results in unique clinical phenotypes that are a function of tissue-specific gene expression, involved pathways, clinical expressivity, and penetrance. This case highlights the utility of next-generation sequencing in patients with an unusual combination of clinical presentations for several pillars of precision medicine including (1) diagnosis, (2) prognosis and outcome, (3) management and therapy, and (4) utilization of resources.

Corresponding author: olaf.bodamer@childrens. harvard.edu

(C) 2020 Rohanizadegan et al. This article is distributed under the terms of the Creative Commons Attribution-NonCommercial

License, which permits reuse and redistribution, except for commercial purposes, provided that the original author and source are credited.

Ontology terms: childhoodonset truncal obesity; intellectual disability, profound; microretrognathia; prominent glabella

Published by Cold Spring Harbor Laboratory Press

doi:10.1101/mcs.a004846

\section{INTRODUCTION}

De novo splice-site, nonsense, and frameshift variants in ASXL1 (additional sex combs-like 1) cause the multisystemic, autosomal dominant Bohring-Opitz syndrome (BOS; OMIM 605039) (Dangiolo et al. 2015). ASXL1, located at 20q11.21, is an enhancer of trithorax and Polycomb (ETP) gene that encodes a protein that regulates transcription of $\mathrm{HOX}$ (Fisher et al. 2003, 2010). Members of the ASXL family of genes also regulate adipogenesis through modulation of PPARY activity; specifically, ASXL1 represses the adipogenesis (Park et al. 2011). ASLX1 protein has 1541 amino acids, and protein truncation due to loss of function variants causes reduction of transcription factor zinc finger $\mathrm{ZIC1}$, which contributes to the BOS phenotype (Matheus et al. 2019). Somatic variants in ASXL1 have been reported in myeloid malignancies. Evidence suggests that this gene may act as a tumor suppressor (Gelsi-Boyer et al. 2009).

The clinical phenotype of BOS is characterized by recognizable craniofacial dysmorphism including microcephaly or trigonocephaly, prominent metopic ridge, synophrys, glabellar and eyelid nevus flammeus, exophthalmus, hypertelorism, palate anomalies, and micrognathia. Other features include severe intrauterine growth retardation, poor feeding, failure to thrive, profound intellectual disability, flexion of elbows with ulnar deviation, and flexion of wrists and metacarpophalangeal joints (Russell et al. 1993; Hoischen et al. 2011; Visayaragawan et al. 2017). Minor cardiac anomalies and increased risk of Wilms' tumor have been reported (Russell et al. 2015). Although the phenotype of BOS can be highly variable, severe prenatal and postnatal growth deficiencies have consistently been noted in all reported cases (Russell et al. 2015). Obesity, on the other hand, has only been reported in 
COLD SPRING HARBOR Molecular Case Studies
Bohring-Opitz syndrome and monogenic obesity one case when the patient's body mass index (BMI) increased significantly in early childhood (Pierron et al. 2009).

Although obesity is a complex and multifactorial disorder, several genes have been identified as causes for monogenic obesity. Leptin (LEP) (Montague et al. 1997; Strobel et al. 1998) and its related genes (Leptin receptor [LEPR], pre-pro-opiomelanocortin [POMC] [Krude et al. 1998], and melanocortin-4 receptor [MC4R] [Vaisse et al. 1998]) are the first genes that have been associated with monogenic obesity (Geets et al. 2018). MC4R variants are the most common cause of monogenic form of obesity in European populations (Hinney et al. 2013). The MC4R protein has 332 amino acids, and its loss-of-function variants causing protein truncation are known to lead to obesity (Vaisse et al. 1998; Yeo et al. 1998). Penetrance and expression of MC4R variants are variable within and between family members. Among family members with MC4R variants, some have no obesity at all, some have early-onset severe childhood obesity, and some have adult-onset obesity (Dubern et al. 2001; Stutzmann et al. 2008).

We report a patient with features of BOS and morbid obesity who was diagnosed through exome sequencing (ES) following a diagnostic odyssey. In this case, ES not only identified a de novo pathogenic variant in ASXL1 but also a likely pathogenic, maternally inherited variant in MC4R, a known monogenic cause for morbid obesity.

\section{RESULTS}

\section{Clinical Presentation and Family History}

An 18-yr-old male was referred for evaluation of intellectual disability, craniofacial dysmorphism, short stature, and obesity.

On physical exam he was found to have hypertelorism with broad and thick eyebrows and left exotropia because of a prior injury. His glabella was prominent with a nevus flammeus covering most of his forehead. He had mild micrognathia with simple, normally set ears (Fig. 1). His achieved ranges of motion were as follows: glenohumeral forward flexion and abduction to $\sim 150^{\circ}$; full elbow extension; forearm supination to neutral left and full supination right; and bilateral neutral dorsiflexion of the wrist. His knees were fixed at $90^{\circ}$ flexion and his hips at $120^{\circ}$, which required him to sit in a wheelchair. He had severe planovalgus foot deformities bilaterally. His muscle tone was reduced, although his muscle strength was preserved. The remainder of his physical exam was within normal limits. His weight was $86.8 \mathrm{~kg}$ (>90 centile), height was $162.4 \mathrm{~cm}$ (<3rd centile), and occipitofrontal circumference was $57 \mathrm{~cm}$ (65th centile). His BMl was >98th centile (moderate obesity, BMI $32.9 \mathrm{~kg} / \mathrm{m}^{2}$ ). His growth curve is shown in Figure 2.

He was born full-term to healthy, nonconsanguineous parents following an uncomplicated pregnancy. The family history was noncontributory. The maternal BMI is within normal limits (currently 24.3). Early infancy was complicated by muscular hypotonia and feeding difficulties, resulting in failure to thrive during the first year of life (Fig. 2). His cognitive and speech development were significantly delayed. At $10 \mathrm{yr}$, he developed generalized epileptic seizures and responded well to levetiracetam. At $14 \mathrm{yr}$, he exhibited self-injurious behavior including head banging that led to retinal detachment in one eye. The self-injurious behavior improved following treatment with gabapentin and topiramate, respectively, although never completely resolved to date. A brain MRI at $15 \mathrm{yr}$ of age showed a $7 \mathrm{~mm} \times$ $5 \mathrm{~mm} \times 5 \mathrm{~mm}$ lesion in the right pontine without enhancement following contrast, and it was thought not to be clinically significant. Magnetic resonance spectroscopy was within normal limits. At $15 \mathrm{yr}$ of age, he was also noted to gain significant weight despite dietary intervention and continued to do so until the present day. 


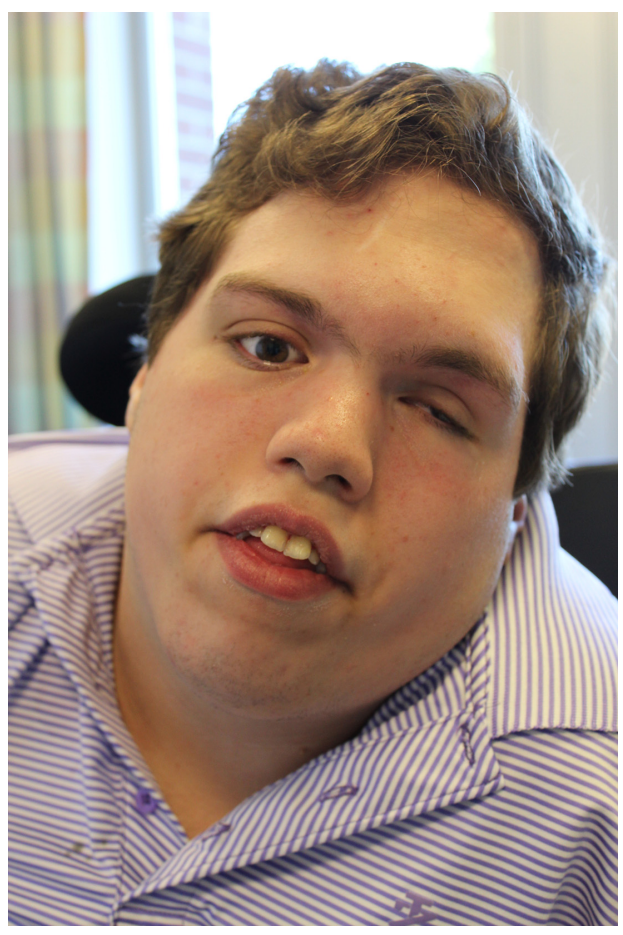

Figure 1. Proband at $18 \mathrm{yr}$ of age.
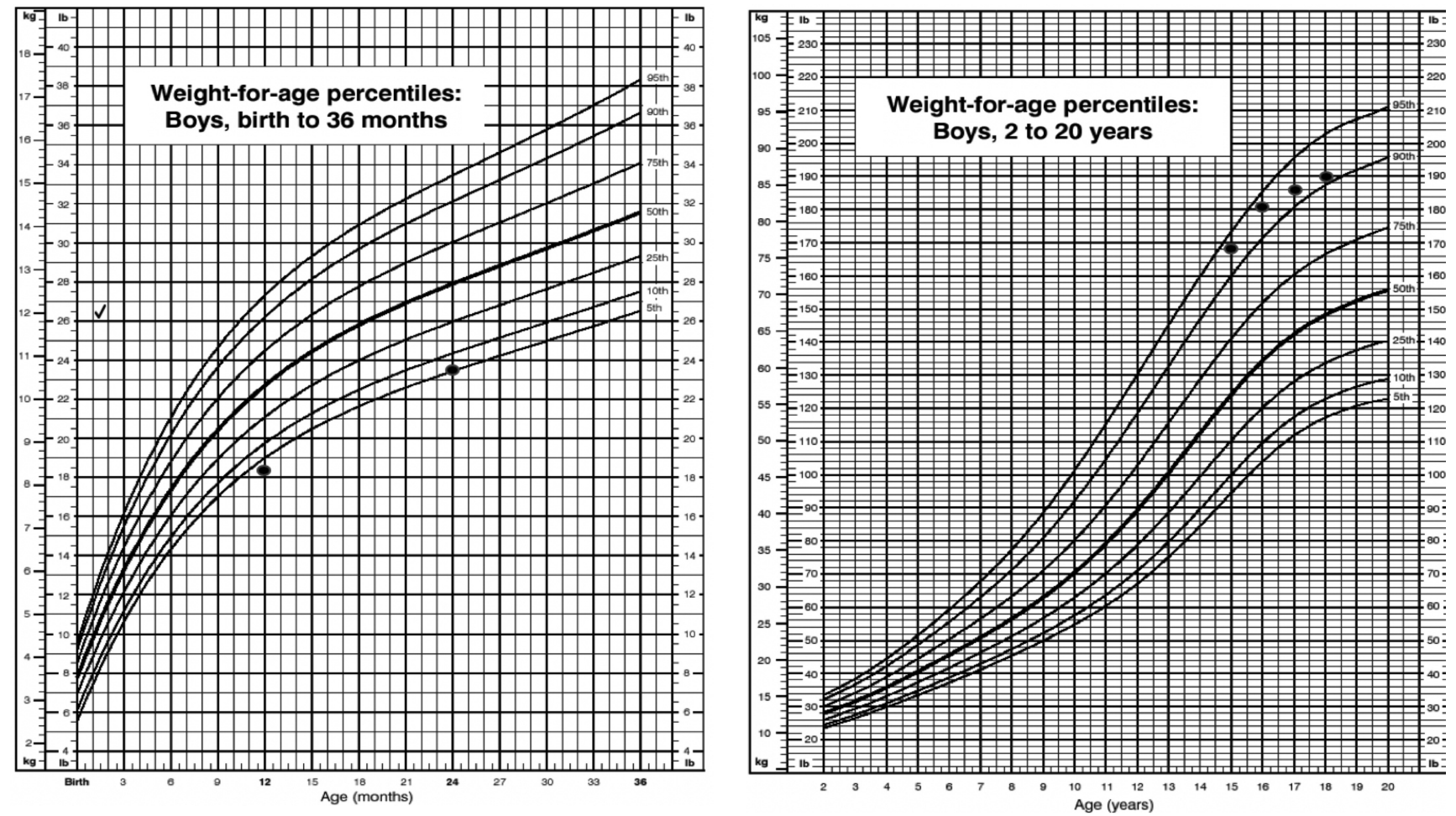

Figure 2. Weight charts. 
COLD SPRING HARBOR Molecular Case Studies
Bohring-Opitz syndrome and monogenic obesity
Prior to ES, he underwent extensive metabolic and genetic testing, which were all unremarkable. Testing included plasma total/free carnitine and acylcarnitine profiles, amino acids, lactic and pyruvic acids, 7-dehydrocholesterol, urine amino acids, acylglycines, mucopolysaccharides, oligosaccharides, and organic acids in addition to chromosomal microarray, karyotype, methylation studies for Prader-Willi syndrome, mitochondrial DNA sequencing and deletion/duplication testing, single-gene testing for SLC9A6 (Angelman-like syndrome), MECP2 (Rett syndrome), STK9/CDKL5 (atypical Rett syndrome), ATP6AP2 and SYN1 (epilepsy), SLC6A8 (creatine transporter deficiency), and OPHN1 (intellectual disability).

At 18 mo of age, he underwent a muscle biopsy. Microscopy showed mild myofiber size variation with mild increase in type I fibers. Immunohistochemistry staining for complexes II, III, IV, and V of the respiratory chain showed normal distribution. Oxidative phosphorylation enzyme assay revealed complex I activity of $0 \mathrm{nmol} / \mathrm{min} / \mathrm{mg}$ (reference $>33$; 5 th percentile) and low complex IV activity of $210 \mathrm{nmol} / \mathrm{min} / \mathrm{mg}$ (reference $>923$; 5th percentile). It was thought that these deficiencies in complexes I and IV could be primary or secondary.

\section{Genomic Analyses}

ES was run on nuclear and mitochondrial genome, as part of the diagnostic workup on peripheral blood samples of the proband and his parents. Variants were confirmed by Sanger sequencing (XomeDx). Coverage information for ES is provided in Table 1. We used American College of Medical Genetics (ACMG) guidelines for variant interpretation in order to classify the variants (Richards et al. 2015). ES revealed heterozygous variants in ASXL1 and MC4R: one de novo, pathogenic variant in exon 13 of ASXL1, c.4198G>T (p.E1400X) (NM_015338.5) and one maternally inherited, likely pathogenic variant in exon 1 of MC4R, c.817C>T (p.Q273X) (NM_005912.2) (Table 2). Neither variant was listed in either the Human Genome Mutation Database (http://www.hgmd.cf.ac.uk/ac/index.php) (Stenson et al. 2017), ClinVar database (http://www.ncbi.nlm.nih.gov/clinvar), or gnomAD database (https://gnomad.broadinstitute.org/). Both variants in this case were predicted to cause loss of normal protein function through protein truncation with loss of at least an 142-amino acid residue for the c.4198G>T variant and loss of the last 60 amino acids for the $c .817 \mathrm{C}>\mathrm{T}$ variant. We did not have any cell lines from the patient to check the protein function.

There were no exons that were called as deletions by the pipeline, and manual review of the normalized coverage data showed that no exons were significantly deviated from the normal-copy expectation, indicating that an exon-level deletion is unlikely.

\section{DISCUSSION}

Dual genetic diagnoses are rare but have been reported in the literature (Wallis et al. 2016). It is estimated that $\sim 4 \%-6 \%$ of children diagnosed with a genetic disease also have a second,

\begin{tabular}{|c|c|c|c|c|c|c|c|c|c|}
\hline Sample & $\begin{array}{l}\text { Mean RefSeq } \\
\text { CDS coverage }\end{array}$ & $\begin{array}{c}\text { RefSeq } \\
\text { CDS } \geq 10 \times \\
(\%)\end{array}$ & $\begin{array}{c}\text { ASXL1 } \\
\text { c.4198G >T } \\
\text { (var/total) }\end{array}$ & $\begin{array}{c}\text { MC4R } \\
\text { c.817C>T } \\
\text { (var/total) }\end{array}$ & $\begin{array}{c}\text { Mean } \\
\text { coverage }\end{array}$ & $\begin{array}{c}\text { c. } 4198 \mathrm{G}>\mathrm{T} \\
\text { (reads) }\end{array}$ & $\begin{array}{c}\text { c.817 C>T } \\
\text { (reads) }\end{array}$ & $\begin{array}{l}\text { Sequence } \\
\text { read length } \\
(\mathrm{bp})\end{array}$ & $\begin{array}{l}\text { Sequence } \\
\text { read type }\end{array}$ \\
\hline Proband & 145 & 98.57 & $152 / 258$ & $102 / 206$ & 145 & 258 & 206 & $2 \times 150$ & Paired end \\
\hline Mother & 264 & 98.68 & $0 / 432$ & $196 / 366$ & 264 & 432 & 366 & $2 \times 150$ & Paired end \\
\hline Father & 159 & 98.68 & $0 / 241$ & $0 / 190$ & 159 & 241 & 190 & $2 \times 150$ & Paired end \\
\hline
\end{tabular}




\begin{tabular}{|c|c|c|c|c|c|c|c|c|}
\hline Gene & Chromosome & $\begin{array}{l}\text { HGVS } \\
\text { DNA }\end{array}$ & Accession no. & $\begin{array}{l}\text { HGVS } \\
\text { protein }\end{array}$ & Variant & Effect & ClinVar & Inheritance \\
\hline$A S X L 1$ & $\begin{array}{l}\text { GRCh37:Chr 20:31024713 } \\
\text { GRCh38:Chr 20:32436910 }\end{array}$ & c. $4198 \mathrm{G}>\mathrm{T}$ & NM_015338.5 & p.E1400X & Nonsense & $\begin{array}{l}\text { Path (PVS1,PS2, } \\
\text { PM2, PM4,PP4) }\end{array}$ & 450465 & De novo \\
\hline$M C 4 R$ & $\begin{array}{l}\text { GRCh37:Chr 18:58038766 } \\
\text { GRCh38:Chr 18: } 60371533\end{array}$ & c. $817 C>T$ & NM_005912.2 & p.Q2273X & Nonsense & $\begin{array}{l}\text { Likely path (PVS1, } \\
\text { PM2,PM4) }\end{array}$ & 450466 & Maternal \\
\hline
\end{tabular}

(Chr) Chromosome, (no) number, (path) pathogenic, (PVS) pathogenic very strong, (PS) pathogenic strong, (PM) pathogenic moderate, (PP) pathogenic supporting.

independent genetic diagnosis (Yang et al. 2013; Stavropoulos et al. 2016; Posey et al. 2017; Trujillano et al. 2017). These concurrent diagnoses can present with unique phenotypes; this aggravates the difficulty of making a diagnosis solely based on the phenotype of the patient. This can be particularly challenging and misleading when the two genetic conditions present with contradicting clinical features. Therefore, single-gene tests or even gene panel testing may prove futile for solving such cases. In contrast, clinical ES is recommended as a comprehensive approach for identification of underlying genetic disorders (Yang et al. 2013). ES has the advantage of enabling us to diagnose two or more pathogenic variants in different parts of the genome; in comparison, targeted genetic diagnostic methods such as panel testing only focus on narrow differential gene lists.

Although ES is particularly advantageous in diagnosis of dual-gene disorders, it may still be difficult to delineate the contribution of each variant to the phenotype, especially when overlapping features exist between syndromes. In fact, this makes the treatment and management plan even more puzzling. In our case, this was not a limitation because the case had presented with a distinctly unusual phenotype (i.e., severe obesity in the presence of BOS).

$\mathrm{BOS}$ is a rare genetic syndrome with dysmorphic features, severe intellectual disability, poor growth, and skeletal abnormalities. Virtually all patients with this condition struggle with poor feeding and growth restriction, which causes significant morbidity and mortality (Russell et al. 2015). Obesity is not a usual feature and has only been reported in one case previously. This patient had significant increase in her BMI from 10.8 to 23.9 between age 3 and 5.5, corresponding to a change from a Z-score of -4.5 to +7 . This rapid weight gain was not explained by medications or endocrinological problems (Pierron et al. 2009). In contrast, our case indeed had all the classic features of BOS, but the MC4R variant likely caused abnormal accumulation of body fat, thereby rescuing the patient from failure to thrive at age 15 and putting him on the other end of the spectrum for weight (i.e., >98th percentile for $\mathrm{BMI})$, contradicting the classical presentation of BOS. The role of ASXL1 in the regulation of adipogenesis (Park et al. 2011) can also be possibly affected by a second variant and may cause enhanced adipogenesis instead of suppression in classic BOS.

Our proband is also one of the oldest known patients with BOS, with only one other patient reported in the literature who lived until $24 \mathrm{yr}$ of age; that patient also suffered from feeding difficulties and failure to thrive in infancy (Hoischen et al. 2011). The exact impact of the MC4R variant on the ASXL1 variant and his prognosis is unclear, but it may be the reason for his nonclassical phenotype (i.e., obesity in teen years).

The case reported herein signifies how the presence of a second genetic diagnosis can modify the classic presentation of a well-described syndrome, and why the possibility of a genetic dual diagnosis should be considered in cases with unusual phenotypical features. This case highlights the utility of ES in patients with unique, unrecognizable phenotypes for several domains of precision medicine including (1) diagnosis, (2) prognosis and outcome, (3) management and therapy, and (4) utilization of resources. 
COLD SPRING HARBOR Molecular Case Studies
Bohring-Opitz syndrome and monogenic obesity

\section{METHODS}

\section{Exome Sequencing}

Exome sequencing was performed at GeneDx following targeted exon capture with the Clinical Research Exome kit (Agilent Technologies) on an Illumina HiSeq $25002 \times 100 \mathrm{bp}$. Both the sequencing technology and variant interpretation protocols have previously been described (Tanaka et al. 2015). The general assertion criteria for variant classification are publicly available on the GeneDx ClinVar submission page (http://www.ncbi.nlm.nih .gov/clinvar/submitters/26957/). The GeneDx pipeline also detects exon-level copy-number changes with single-exon resolution for deletions (Retterer et al. 2015).

\section{ADDITIONAL INFORMATION}

\section{Data Deposition and Access}

Our patient consent does not permit patient sequence data to be uploaded to a data repository. The variants reported have been deposited in the ClinVar (http://www.ncbi.nlm.nih .gov/clinvar/) database and can be found under accession numbers SCV000619055.1 (ASXL1:c.4198G>T (p.Glu1400Ter)) and SCV000619056.2 (MC4R:c.817C>T (p.Gln273Ter)).

\section{Ethics Statement}

The family was enrolled in The Manton Center for Orphan Disease Research, Gene Discovery Core under informed consent governed by the Institutional Review Board of Boston Children's Hospital (IRB number is 10-02-0053). Written informed consent was provided by both parents for research and publication.

Competing Interest Statement

The authors have declared no competing interest.

\section{Referees}

Peter N. Robinson

Anonymous

Received October 16, 2019; accepted in revised form December 18, 2019.

\section{Acknowledgments}

We thank the family for their interest in this work and willingness to participate in the research study. We thank the Gene Discovery Core of The Manton Center for Orphan Disease Research for providing resources and support in patient consenting, sample collection, sequencing, and sharing of information and samples.

\section{Author Contributions}

M.R., A.S., and O.B. contributed to patient recruitment and phenotyping. M.R., A.S., C.H., and O.B. contributed to writing the initial draft of the manuscript. All authors contributed to revising the manuscript and reviewing the final draft.

\section{REFERENCES}

Dangiolo SB, Wilson A, Jobanputra V, Anyane-Yeboa K. 2015. Bohring-Opitz syndrome (BOS) with a new ASXL1 pathogenic variant: review of the most prevalent molecular and phenotypic features of the syndrome. Am J Med Genet A 167A: 3161-3166. doi:10.1002/ajmg.a.37342

Dubern B, Clément K, Pelloux V, Froguel P, Girardet JP, Guy-Grand B, Tounian P. 2001. Mutational analysis of melanocortin-4 receptor, agouti-related protein, and a-melanocyte-stimulating hormone genes in severely obese children. J Pediatr 139: 204-209. doi:10.1067/mpd.2001.116284

Fisher CL, Berger J, Randazzo F, Brock HW. 2003. A human homolog of Additional sex combs, ADDITIONAL SEX COMBS-LIKE 1, maps to chromosome 20q11. Gene 306: 115-126. doi:10.1016/S0378-1119(03) 00430-X 
Fisher CL, Lee I, Bloyer S, Bozza S, Chevalier J, Dahl A, Bodner C, Helgason CD, Hess JL, Humphries RK, et al. 2010. Additional sex combs-like 1 belongs to the enhancer of trithorax and Polycomb group and genetically interacts with Cbx2 in mice. Dev Biol 337: 9-15. doi:10.1016/j.ydbio.2009.10.004

Geets E, Meuwissen MEC, Van Hul W. 2018. Clinical, molecular genetics and therapeutic aspects of syndromic obesity. Clin Genet 95: 23-40. doi:10.1111/cge.13367

Gelsi-Boyer V, Trouplin V, Adélaïde J, Bonansea J, Cervera N, Carbuccia N, Lagarde A, Prebet T, Nezri $M$, Sainty $D$, et al. 2009. Mutations of Polycomb-associated gene ASXL1 in myelodysplastic syndromes and chronic myelomonocytic leukaemia. Br J Haematol 145: 788-800. doi:10.1111/j.1365-2141.2009 .07697.x

Hinney A, Volckmar A-L, Knoll N. 2013. Melanocortin-4 receptor in energy homeostasis and obesity pathogenesis. Prog Mol Biol Transl Sci 114: 147-191. doi:10.1016/B978-0-12-386933-3.00005-4

Hoischen A, van Bon BWM, Rodríguez-Santiago B, Gilissen C, Vissers LELM, de Vries P, Janssen I, van Lier B, Hastings $R$, Smithson SF, et al. 2011. De novo nonsense mutations in ASXL1 cause Bohring-Opitz syndrome. Nat Genet 43: 729-731. doi:10.1038/ng.868

Krude H, Biebermann H, Luck W, Horn R, Brabant G, Grüters A. 1998. Severe early-onset obesity, adrenal insufficiency and red hair pigmentation caused by POMC mutations in humans. Nat Genet 19: 155-157. doi:10.1038/509

Matheus F, Rusha E, Rehimi R, Molitor L, Pertek A, Modic M, Feederle R, Flatley A, Kremmer E, Geerlof A, et al. 2019. Pathological ASXL1 mutations and protein variants impair neural crest development. Stem Cell Rep 12: 861-868. doi:10.1016/j.stemcr.2019.03.006

Montague CT, Farooqi IS, Whitehead JP, Soos MA, Rau H, Wareham NJ, Sewter CP, Digby JE, Mohammed $\mathrm{SN}$, Hurst JA, et al. 1997. Congenital leptin deficiency is associated with severe early-onset obesity in humans. Nature 387: 903-908. doi:10.1038/43185

Park U-H, Yoon SK, Park T, Kim E-J, Um S-J. 2011. Additional sex comb-like (ASXL) proteins 1 and 2 play opposite roles in adipogenesis via reciprocal regulation of peroxisome proliferator-activated receptor $\gamma$. J Biol Chem 286: 1354-1363. doi:10.1074/jbc.M110.177816

Pierron S, Richelme C, Triolo V, Mas JC, Griffet J, Karmous-Benailly H, Quere M, Kaname T, Lambert J-C, Giuliano F. 2009. Evolution of a patient with Bohring-Opitz syndrome. Am J Med Genet A 149A: 17541757. doi:10.1002/ajmg.a.32910

Posey JE, Harel T, Liu P, Rosenfeld JA, James RA, Coban Akdemir ZH, Walkiewicz M, Bi W, Xiao R, Ding Y, et al. 2017. Resolution of disease phenotypes resulting from multilocus genomic variation. N Engl J Med 376: 21-31. doi:10.1056/NEJMoa1516767

Retterer K, Scuffins J, Schmidt D, Lewis R, Pineda-Alvarez D, Stafford A, Schmidt L, Warren S, Gibellini F, Kondakova $A$, et al. 2015. Assessing copy number from exome sequencing and exome array CGH based on CNV spectrum in a large clinical cohort. Genet Med 17: 623-629. doi:10.1038/gim.2014.160

Richards S, Aziz N, Bale S, Bick D, Das S, Gastier-Foster J, Grody WW, Hegde M, Lyon E, Spector E, et al. 2015. Standards and guidelines for the interpretation of sequence variants: a joint consensus recommendation of the American College of Medical Genetics and Genomics and the Association for Molecular Pathology. Genet Med 17: 405-424. doi:10.1038/gim.2015.30

Russell B, Tan W-H, Graham JM. 1993. Bohring-Opitz syndrome. http://www.ncbi.nlm.nih.gov/pubmed/ 29446906

Russell B, Johnston JJ, Biesecker LG, Kramer N, Pickart A, Rhead W, Tan W-H, Brownstein CA, Kate Clarkson L, Dobson A, et al. 2015. Clinical management of patients with ASXL1 mutations and Bohring-Opitz syndrome, emphasizing the need for Wilms' tumor surveillance. Am J Med Genet A 167A: 2122-2131. doi:10.1002/ajmg.a.37131

Stavropoulos DJ, Merico D, Jobling R, Bowdin S, Monfared N, Thiruvahindrapuram B, Nalpathamkalam T, Pellecchia G, Yuen RKC, Szego MJ, et al. 2016. Whole genome sequencing expands diagnostic utility and improves clinical management in pediatric medicine. NPJ Genom Med 1: 15012. doi:10.1038/ npjgenmed.2015.12

Stenson PD, Mort M, Ball E V, Evans K, Hayden M, Heywood S, Hussain M, Phillips AD, Cooper DN. 2017. The Human Gene Mutation Database: towards a comprehensive repository of inherited mutation data for medical research, genetic diagnosis and next-generation sequencing studies. Hum Genet 136: 665-677. doi:10.1007/s00439-017-1779-6

Strobel A, Issad T, Camoin L, Ozata M, Strosberg AD. 1998. A leptin missense mutation associated with hypogonadism and morbid obesity. Nat Genet 18: 213-215. doi:10.1038/ng0398-213

Stutzmann F, Tan K, Vatin V, Dina C, Jouret B, Tichet J, Balkau B, Potoczna N, Horber F, O'Rahilly S, et al. 2008. Prevalence of melanocortin-4 receptor deficiency in Europeans and their age-dependent penetrance in multigenerational pedigrees. Diabetes 57: 2511-2518. doi:10.2337/db08-0153

Tanaka AJ, Cho MT, Millan F, Juusola J, Retterer K, Joshi C, Niyazov D, Garnica A, Gratz E, Deardorff M, et al. 2015. Mutations in SPATA5 are associated with microcephaly, intellectual disability, seizures, and hearing loss. Am J Hum Genet 97: 457-464. doi:10.1016/j.ajhg.2015.07.014 
COLD SPRING HARBOR

Molecular Case Studies
Bohring-Opitz syndrome and monogenic obesity

Trujillano D, Bertoli-Avella AM, Kumar Kandaswamy K, Weiss ME, Köster J, Marais A, Paknia O, Schröder R, Garcia-Aznar JM, Werber M, et al. 2017. Clinical exome sequencing: results from 2819 samples reflecting 1000 families. Eur J Hum Genet 25: 176-182. doi:10.1038/ejhg.2016.146

Vaisse C, Clement K, Guy-Grand B, Froguel P. 1998. A frameshift mutation in human MC4R is associated with a dominant form of obesity. Nat Genet 20: 113-114. doi:10.1038/2407

Visayaragawan N, Selvarajah N, Apparau H, Kamaru Ambu V. 2017. Bohring-Opitz syndrome: a case of a rare genetic disorder. Med J Malaysia 72: 248-249.

Wallis M, Tsurusaki Y, Burgess T, Borzi P, Matsumoto N, Miyake N, True D, Patel C. 2016. Dual genetic diagnoses: atypical hand-foot-genital syndrome and developmental delay due to de novo mutations in HOXA13 and NRXN1. Am J Med Genet A 170: 717-724. doi:10.1002/ajmg.a.37478

Yang Y, Muzny DM, Reid JG, Bainbridge MN, Willis A, Ward PA, Braxton A, Beuten J, Xia F, Niu Z, et al. 2013. Clinical whole-exome sequencing for the diagnosis of Mendelian disorders. N Engl J Med 369: 15021511. doi:10.1056/NEJMoa1306555

Yeo GS, Faroogi IS, Aminian S, Halsall DJ, Stanhope RG, O'Rahilly S. 1998. A frameshift mutation in MC4R associated with dominantly inherited human obesity. Nat Genet 20: 111-112. doi:10.1038/2404 


\section{COLD SPRING HARBOR Molecular Case Studies}

\section{The tale of two genes: from next-generation sequencing to phenotype}

Mersedeh Rohanizadegan, Aishwarya Siddharath, Kyle Retterer, et al.

Cold Spring Harb Mol Case Stud 2020, 6: a004846 originally published online January 22, 2020 Access the most recent version at doi: $10.1101 / \mathrm{mcs} .0004846$

References This article cites 28 articles, 2 of which can be accessed free at: http://molecularcasestudies.cshlp.org/content/6/2/a004846.full.html\#ref-list-1

License This article is distributed under the terms of the Creative Commons Attribution-NonCommercial License, which permits reuse and redistribution, except for commercial purposes, provided that the original author and source are credited.

Email Alerting Receive free email alerts when new articles cite this article - sign up in the box at the Service top right corner of the article or click here. 